\title{
Corrigendum: Rapid evolution of thermal tolerance in the water flea Daphnia
}

A. N. Geerts, J. Vanoverbeke, B. Vanschoenwinkel, W. Van Doorslaer, H. Feuchtmayr, D. Atkinson, B. Moss, T. A. Davidson, C. D. Sayer and L. De Meester

Nature Clim. Change 5, 665-668 (2015); published online 27 April 2015; corrected after print 3 September 2015

In the version of this Letter originally published, in Fig. 1a, the boxplot for the Ambient $+4{ }^{\circ} \mathrm{C}$ treatment was incorrect. This error has been corrected in the online versions. 